\title{
Credit Take over Agreements with Guarantees of Mortgage Rights at Bank China Construction Bank Indonesia TBK. Pekanbaru Branch
}

\author{
May Er Rosary Indah; Yulfasni; Yussy Adelina Mannas \\ Notary Masters Program, Faculty of Law, Andalas University, Indonesia
}

http://dx.doi.org/10.18415/ijmmu.v6i5.1088

\begin{abstract}
Credit take over agreements with guarantees of Mortgage Rights in the banking world can still be said to be attractive because CCB Indonesia Pekanbaru Branch is carrying out a binding agreement on take-over credit and Power of Attorney Imposing Mortgage Rights with the conditions of Land Rights Certificates and Mortgage Certificates still attached Mortgage rights for the Initial Creditors / Banks that are taken over. CCB Indonesia in approving the take over credit facility with the main consideration being that the debtor has a history of credit collectibility in the Debtor Information for the Financial Information Service System / IDEB SLIK OJK with current credit collectability. Debtors choose to take over credit facilities to CCB Indonesia because they obtain lower lending credit interest rates, higher credit facility ceilings, faster approval processes and credit decision making compared to Initial Creditors, free of administrative fees and free of notary fees. The main problem in this study is how to take over credit agreements with guaranteed mortgage rights at Bank China Construction Bank Indonesia Tbk. Pekanbaru Branch. How is the legal protection for the parties with a credit take-over agreement (take over) with guaranteed Mortgage Rights at Bank China Construction Bank Indonesia Tbk. Pekanbaru Branch. The method used in this research is empirical juridical research. Respondents / Informants as well as samples in this study are Credit Operations Head of "CCB Indonesia" Pekanbaru Branch of 1 (one) person and 7 (seven) Notary Partners of "CCB Indonesia" of Pekanbaru Branch. Data collection tool in this study was in the form of an interview. This research is descriptive in nature, providing complete and clear data on loan takeover agreements with guaranteed mortgage rights at Bank China Construction Bank Indonesia Tbk. Pekanbaru Branch. The results of the author's research indicate that the specificity of the credit takeover agreement (guarantee over) with guaranteed Mortgage in Article 3 explicitly specifies that currently the object of Mortgage Guarantee is still in the initial creditor / bank (taken over) and Article 4 expressly specifies that The debtor will transfer the funds to the initial creditor / bank account (taken over) from the proceeds from the disbursement of credit facilities obtained by the Debtor from the CCB Indonesia Pekanbaru Branch. After the signing of the credit agreement has been fulfilled, the Partner Notary issues a Cover Note / Certificate submitted to CCB Indonesia to continue the transfer of funds to the Debtor account at the Initial Creditors / Banks which are overtaken. Legal protection for the Parties in the Take Over Agreement with guaranteed Mortgage is carried out in 2 (two) forms, namely preventive and repressive from CCB Indonesia Creditor and Partner Notary.
\end{abstract}

Keywords: Credit Take Over Agreement; Mortgage Rights 


\section{A. Background}

The State of Indonesia is a state of law, this is contained in Article 1 Paragraph (3) of the Constitution of the Republic of Indonesia (hereinafter abbreviated to the 1945 Constitution). As a consequence of understanding the rule of law, all walks of life in society, nation and state must obey the legal norms prevailing in Indonesia. Indonesia as a legal state based on the Pancasila and the 1945 Constitution should ensure certainty, order and legal protection for every citizen ${ }^{1}$. For human interests to be protected, the law must be implemented. Implementation in law can run normally, orderly and effectively, but violations of the law can also occur. In the event of a violation of the law, enforcement efforts must be carried out by the authorized apparatus and through law enforcement this law becomes a reality ${ }^{2}$.

As in realizing a just and prosperous Indonesia based on Pancasila and the 1945 Constitution that is sustainable and promoting national development based on power and prosperity, it is necessary to create harmony in economic development. To support the business world in the context of creating community welfare, it certainly cannot be separated from capital problems. Capital providers that can cash are banks. Banking has a very important role in economic development because it functions as a strategic intermediary in placing the economy and can even be called the heart of the economy.

The strategic role of banking institutions that carry out the main task as a vehicle that can collect and distribute funds effectively and efficiently, requires continuous improvement in order to be able to have a comparative advantage ${ }^{3}$. The bank is one of the financial intermediaries. As a financial intermediary institution, banks have excess funds (surplus of funds) and channel them to those who need funds (lack of funds) ${ }^{4}$.

One function of banking institutions in the context of developing the community's economy is the distribution of credit facilities. According to the provisions of Article 1 Number 11 of Law Number 7 of 1992 concerning Banking in conjunction with Law Number 10 of 1998 concerning Amendment to Law Number 7 of 1992 (hereinafter referred to as the Banking Law) which formulates the notion of credit, namely:

"Credit is the provision of money or bills that can be equated with that, based on a loan agreement or agreement between the bank and another party that requires the borrower to repay the debt after a certain period of time with the provision of interest".

The implementation of channeling credit facilities to the public so that banks in providing credit facilities must pay attention to the principles and other aspects of credit that aim to make the credit channeled right on target. This is necessary for a policy from the bank in the beginning to provide an explanation of the credit facilities to be provided to the borrower.

All credit granting is essentially a loan agreement as stipulated in Article 1754 through Article 1769 of the Civil Code (hereinafter referred to as the Civil Code). A loan agreement is an agreement with which one party gives the other party a certain amount of goods that are used up due to usage, on

\footnotetext{
${ }^{1}$ General explanation Undang-Undang Nomor 2 Tahun 2014 atas Perubahan Undang-Undang Nomor 30 Tahun 2004 Tentang Jabatan Notaris.

${ }^{2}$ Sjaifurrachman,2011, Aspek Pertanggungjawaban Notaris dalam Pembuatan Akta, Mandar Maju, Bandung, p. 1.

${ }^{3}$ Neni Sri Imaniyati, 2009, Hukum Bisnis Telaah tentang Pelaku dan Kegiatan Ekonomi, Graha Ilmu, Yogjakarta, p. 91.

${ }^{4}$ Ibid., p.92
} 
condition that the latter returns the same amount of the same type and quality ${ }^{5}$. Business activities in granting credit in order to obtain profit so that banking institutions must be selective in forwarding public funds to prospective debtors who will receive credit facilities are able and willing to return the credit ceiling and credit interest as well as legal provisions agreed upon by both parties contained in the credit agreement.

Banking practice activities, there are no specific provisions governing credit takeover agreements (take over), the form and format of credit takeover agreements (take over) are left entirely to the bank. The guidelines in formulating a take over agreement must be clear or not vague, in accordance with the legal terms of the agreement. For other collateral imposition agreements required or required to use an authentic deed, if not using an authentic deed, are threatened with null and void. Naturally the granting of the bail must be done in advance and in front of the general official in charge for it ${ }^{6}$.

According to Mariam Darus Badrulzaman to formulate guarantees as a responsibility given by a debtor and / or third party to creditors to guarantee their obligations in an agreement ${ }^{7}$. The same was stated by Hartono Hadisaputro, who stated that collateral is something given by the debtor to the creditor to create confidence that the debtor will fulfill obligations that can be valued with money arising from an agreement ${ }^{8}$. According to H.R.Daeng Naja, the definition of collateral is a responsibility given by the debtor and / or a third party to the creditor because the creditor has an interest that the debtor must fulfill his obligations in an engagement ${ }^{9}$.

Judging by the provisions in Article 1131 of the Civil Code which stipulate that all debts, both movable and immovable, both existing and new will be in the future, become dependents for all individual engagement. The principle of providing guarantees can be divided into 2 (two) characteristics, namely general guarantee and special guarantee. Guarantees that are general are intended for all creditors without having the right to receivables to overtake one creditor with another creditor (concurrent creditor) for guarantees given by the debtor. Special collateral means that there is a privilege that takes precedence to the preverent creditor if the debtor is unable to repay the debt to the creditor for the credit guarantee given.

The existence of a collateral is an important prerequisite for minimizing the bank's risk of lending. The guarantee given to the creditor is either an Individual guarantee or a material guarantee. The guarantee given to the bank is required to have an accreditation guarantee in the nature of the credit agreement.

Materialized warranty (zakelijk) is the existence of certain things as security. Legal knowledge does not limit the material that can be secured, the origin of the property must be the property of the person providing the mortgage, lien, mortgage and fiduciary ${ }^{10}$. According to H.R. Daeng Naja formulated that the definition of property guarantee is the guarantee of any property, property or property rights, provided by way of partition of the property, either from the debtor or the third party, to ensure the fulfillment of the debtor's obligations to the creditor when the debtor in relation to the injuries of the promise $^{11}$. This means that the credit guarantee provided by the debtor must be performed by the credit bureau in accordance with the credit bureaus.

\footnotetext{
${ }^{5}$ Subekti,1991,Jaminan-Jaminan untuk Pemberian Kredit menurut Hukum Indonesia, cetakan ke-5,Citra Aditya Bakti, Bandung, p. 3

${ }^{6}$ Rachmadi Usman, 2009,Hukum Jaminan Keperdataan, Sinar Grafika, Jakarta, p. 88

${ }^{7}$ Mariam Darus Badrulzaman,2000,Beberapa Permasalahan Hukum Hak Jaminan, Jurnal Hukum Bisnis Vol. 11, Jakarta, p. 12.

${ }^{8}$ Hartono Hadisaputro,1984, Seri Hukum Perdata Pokok-Pokok Hukum Perdata dan Hukum Jaminan, Liberty, Yogyakarta,p. 50.

${ }^{9}$ H.R. Daeng Naja,2005, Hukum Kredit dan Bank Garansi-The Bankers Hand Book, PT.Citra Aditya Bakti, Bandung, p. 208.

${ }^{10}$ Herlien Budiono,2008,KumpulanTulisan Hukum Perdata di Bidang Kenotariatan, Citra Aditya Bakti, Bandung, p. 234.

${ }^{11}$ H.R. Daeng Naja, Op.Cit., p. 214
} 
The most popular item used as collateral in the lending facility is land, as landlords are generally easy to sell and economically costly increase over time compared to non-land warranty items, and land can be burdened with Liability. Pursuant to the provisions of Article 1 Number 1 of Law No. 4 of 1996 on Land Rights and Land Related Matters (hereinafter the Rights of Persons) which formulate the definition of Land Rights is:

"The right of assurance imposed on land rights as defined in Law No. 5 of the Agrarian Laws, following or not following other things that are one unit with the land, for the settlement of certain debts, provides a position favorable to certain Creditors over other Creditors. ",I2

The above description of the Rights of Tenants is basically confined to the rights of the land and often there are things above it that can be buildings, crops and other crops that are still one unit with the land being guaranteed. Pursuant to Article 4 Paragraph (1) of the Copyright Law that the object of its guarantee shall be the right of land transferable by the holder of such rights as Ownership, Business Rights, and Use Rights, and Use Rights on State lands in accordance with applicable law. registered and transferable properties may also be subject to Liability. The provisions of Article 15 Paragraph (3) of Law No. 4 of 1996 of the Land Rights Act that the Authorization of the Restricting Rights of Landlords in respect of the rights of a registered land shall be followed by the making of the Grant of Rights within a period of one (1) month after the grant.

One of the banking services that the banking institution currently enjoys and offers to the public is in the form of take over. Take over (hereafter referred to as credit taking) in English - Indonesian dictionary means taking over ${ }^{13}$. Some of the reasons prospective debtors apply to take on a new credit takeover agreement are because they have higher credit facilities than creditors, more competitive bank rates, and more advanced banking service processes.

The takeover credit agreement with the Warranty of Liability at CCB Indonesia pursuant to the SOP (Standard Operation Procedure) was intended to be used as a reference for all executives and staff executing Legal Credit at PT Bank China Construction Bank Indonesia Tbk. hereinafter referred to as "CCB Indonesia").

Based on information obtained by the author from the Credit Operation Head "CCB Indonesia" Pekanbaru Branch as one of the banks operating in Pekanbaru, by providing services in the form of lending credit to the public who need it, in practice since 2011 specifically the object of credit guarantees in the form of Mortgage Rights. The CCB Indonesia Pekanbaru branch carries out a loan overtake agreement (take over) and SKMHT (Power of Attorney Imposing Mortgage Rights) without first checking the certificate or without asking SKPT (Certificate of Land Registration) from the local National Land Agency and only based on information oral and photocopy of documents on land title certificate and Mortgage Certificate (SHT) which are still attached Mortgage from the original creditor.

CCB Indonesia Pekanbaru Branch carries out a credit takeover agreement with guarantee of Mortgage Rights and Power of Attorney Imposing Mortgage Rights (SKMHT) with the condition that the Land Rights Certificate and the Mortgage Certificate (SHT) still have the Mortgage Right attached to the Initial Creditor (hereinafter referred to as a Third Party). Banking services in the form of granting credit facilities "CCB Indonesia" Pekanbaru Branch (hereinafter referred to as the Second Party) by providing credit facilities to prospective debtors (hereinafter referred to as the First Party). The Second Party

\footnotetext{
${ }^{12}$ Undang-Undang No. 4 Tahun 1996 tentang Hak Tanggungan

${ }^{13}$ John M. Echols dkk, 1990, Kamus Inggris-Indonesia,PT.Gramedia Pustaka Utama, Jakarta, p. 578
} 
provides credit facilities to the First Party so that the position of the Third Party is replaced by the Second Party in a credit take-over agreement with a Guarantee of Mortgage Right at the CCB Indonesia Pekanbaru Branch ${ }^{14}$.

Furthermore, Notary / PPAT Mitra CCB Indonesia Pekanbaru Branch issued a Covernote / Certificate by providing information that the binding credit agreement has been carried out and the Power of Attorney Imposing Mortgage Rights (SKMHT) with a period of 1 (one) month from the date of the binding agreement on the takeover credit (take over). Covernote / Notary Certificate / PPAT partner of CCB Indonesia Pekanbaru Branch as a written reference for CCB Indonesia Pekanbaru Branch to carry out the repayment of First Party debt to third parties on the same date as the binding date of the take over agreement. CCB Indonesia Pekanbaru Branch in the service program for providing credit facilities seeks to improve and improve performance, especially in binding loan take-over agreements with guarantees of Mortgage Rights at CCB Indonesia Pekanbaru Branch.

Based on the description above, it increases the author's desire to know more clearly about the credit takeover agreement (take over) with guaranteed Mortgage Rights at PT Bank China Construction Bank Indonesia Tbk. Pekanbaru Branch and legal protection for the parties with a credit take-over agreement (guarantee over) with guaranteed Mortgage Rights at PT Bank China Construction Bank Indonesia Tbk. Pekanbaru Branch. Furthermore, the authors are interested in doing this research and pouring in the form of an article entitled "Take Over Credit Agreement with Guaranteed Mortgage Rights at PT Bank China Construction Bank Indonesia Tbk. Pekanbaru Branch ".

\section{B. Problem Formulation}

Based on the description of the background that has been raised, the writer wants to examine a number of issues including:

How is the agreement to take over credit (guarantee over) with guaranteed Mortgage at PT Bank China Construction Bank Indonesia Tbk. Pekanbaru Branch?

\section{Discussion}

Take Over Agreement with Guarantee of Mortgage Rights at PT Bank China Construction Bank Indonesia Tbk. Pekanbaru Branch

Credit take-over agreements with guarantees of Mortgage Rights in the banking world receive special attention from banks as creditors and debtors who will obtain credit facilities. CCB Indonesia Pekanbaru Branch certainly supports the improvement of the people's economy by continuing to increase portfolios in channeling credit facilities to the people who need them in the Commercial / Working capital and Mortgage / Consumer loan segments by accepting credit collateral objects in the form of Land Rights Certificates that are still attached Mortgage Rights to the initial Creditors. CCB Indonesia in providing

\footnotetext{
14 The author's survey results with the Credit Operation Head of PT Bank China Construction Bank Indonesia Tbk. Pekanbaru branch on October 1, 2018.
} 
offers for lending facilities must have confidence in the debtor's current credit history record in addition to the credit analysis considerations to approve the debtor's request for take over by repaying all debtor debt to the original creditor. Repayment of all debts to the initial creditor for credit disbursement or loan realization from the CCB Indonesia Pekanbaru Branch. Debtors take the decision to transfer their credit facilities to CCB Indonesia Pekanbaru Branch with several considerations offered to debtors who are better than CCB Indonesia Pekanbaru Branch, such as lower interest rates, higher ceiling credit facilities compared to initial creditors.

$\underline{\text { Table III. } 1}$

Debtor Amount Of Bonding Take Over Credit Agreement With Warranty of Liability

\begin{tabular}{|l|l|l|l|}
\hline No. & Year & Commercial / Working Capital & Mortgage / Consumer \\
\hline 1 & 2014 & 10 & 8 \\
\hline 2 & 2015 & 12 & 10 \\
\hline 3 & 2016 & 14 & 12 \\
\hline 4 & 2017 & 15 & 12 \\
\hline 5 & 2018 & 17 & 15 \\
\hline & Amount & 68 & 57 \\
\hline
\end{tabular}

Source: Data PT Bank CCB Indonesia Pekanbaru Branch

Based on the table above, it can be seen that the number of debtors in the Commercial / Working capital and Mortgage / Consumer loan segments each year has increased in binding credit take-over agreements with guaranteed Mortgage Rights at CCB Indonesia Pekanbaru Branch.

Based on the results of the author's interview with the CCB Indonesia Credit Operation Head Pekanbaru Branch on June 17, 2019, regarding the reasons for debtors willing to accept the transfer of credit facilities to CCB Indonesia Pekanbaru Branch because debtors get higher credit facility ceiling offers, lower interest rates, and free of bank administration fees and the cost of binding a take over loan agreement with guaranteed Mortgage ${ }^{15}$.

Referring to the provisions of Article 1338 Paragraph 1 of the Civil Code explains the principle of freedom of contract relating to the contents of the agreement, namely the freedom to determine what and with whom the agreement is entered into ${ }^{16}$. The debtor has the freedom to enter into a loan take-over agreement between the debtor and the creditor with the physical condition that the credit guarantee in the form of a certificate of land rights and a Mortgage Certificate is still bound to the original creditor. The debtor can repay the entire debt to the initial creditor from the credit facility ceiling obtained by the debtor from CCB Indonesia after the signing of the take over agreement between the debtor / as the First Party and CCB Indonesia Pekanbaru Branch / as the Second Party as agreed.

The provision of credit facilities to Debtors by banks certainly carries risks so that in their mechanism banks must pay attention to the principles in granting credit. Several principles are considered in the mechanism of credit granting, principles that need to be considered in accordance with the functions of banking and credit. There are 2 main principles that guide the granting of credit, namely ${ }^{17}$ :

\footnotetext{
${ }^{15}$ Interview with Credit Operation Head on June 17, 2019.

${ }^{16}$ Djaja S Meliala, 2015, "Perkembangan Hukum Perdata Tentang Benda Dan Hukum Perikatan",Nuansa Aulia, Bandung.

${ }^{17}$ Hermansyah, 2008, Hukum Perbankan Nasional Indonesia, Prenada Media Group, Jakarta, p. 61
} 
a. Principle of Trust

Lending credit by banks to customers is always based on trust. Banks have confidence that the loans are beneficial to customers in accordance with their designation, and banks must also believe that customers are able to repay credit loans and interest within the credit period.

\section{b. Prudential Principle}

In addition to the principle of trust given by banks, another principle needed by banks is the principle of prudence. This principle is realized in the form of consistent application based on good faith to all requirements and statutory regulations related to credit granting by the bank concerned.

CCB Indonesia, before disbursing credit facilities to Debtors, must first analyze the credit to ensure that the bank towards the Debtor is truly trustworthy. Credit analysis includes background, business prospects, guarantees provided and other factors. Some considerations in the credit analysis aim to ensure that the credit facilities provided to the Debtor are truly secure and that the credit facility installments can be repaid in accordance with the credit agreement. Therefore, before giving credit, banks must conduct a careful assessment of the character, capital capacity, collateral and business prospects of the debtor customers (condition of economy), commonly referred to as the five $\mathrm{C}$ of Credit Analysis or the 5 C's principle ${ }^{18}$. The CCB Indonesia approver of credit specifically submits the Debtor application letter with the Mortgage Guarantee object which is still bound to the initial creditor has special requirements in fulfilling credit documents. The CCB Indonesia Approver of Credit specifically submits a credit transfer / take over with the signing of a credit takeover agreement (take over) with guaranteed Mortgage, the CCB Indonesia in its main consideration is that the debtor has a record of the credit collectibility history at the bank or the Debtor Information Financial Information Service System / IDEB SLIK OJK with current credit collectability at the bank for the duration of the loan or installment obligations.

Based on interviews with the CCB Indonesia Pekanbaru Credit Operation Head on June 17, 2019 that the mechanism of the Take Over Agreement with Guaranteed Mortgage that has been approved by the debtor credit facility by the approver of credit, the CCB Indonesia Pekanbaru Branch through the Marketing Bank will prepare a Letter Of Offer or Credit Approval Offer (SPPK) which specifies that the credit facility limit has been approved by the debtor and credit requirements that must be fulfilled by the debtor before signing a take over agreement with the overall condition that the collateral object is still attached. Initial creditor. Furthermore, the Marketing Bank must explain in advance to the Debtor related credit documents that must be fulfilled and agreed upon by the Debtor before the signing of the take over credit agreement.

Based on the results of the author's interview with the CCB Indonesia Credit Operation Head Pekanbaru Branch on June 17, 2019 that prior to the signing of the take over agreement with a guarantee of Mortgage, the Debtor has first agreed by signing a Letter of Offer or SPPK ). Letter of Offer or Credit Approval Offer (SPPK) as a Legal Credit reference for submitting an order to the Notary CCB Indonesia Pekanbaru Branch Notary to prepare a draft take-over agreement (take over) with a notary guarantee with a Mortgage Right.

Legal Credit will first carry out a draft review of the Notarial deeds of the Partner, namely the Credit Agreement, SKMHT (Power of Attorney Imposing Mortgage Rights) which will be signed by the parties between the Debtor / As the First Party and the Creditors / As the Second Party in the take over Credit Agreement with the Collateral Rights Dependents. The take over credit agreement specifies several special agreements in Article 3 (three) Guarantees pouring out the conditions of the Land Rights Certificate that are still in the Initial Creditors and also in Article 4 explains that after signing the Credit

\footnotetext{
${ }^{18}$ Djoni S. Gazali, Rachmadi Usman, op.cit.,p. 272
} 
Agreement, the Debtor immediately transfers the funds obtained from the disbursement of credit facilities at CCB Indonesia Pekanbaru Branch to repay credit debt to Initial Creditors ${ }^{19}$.

The Debtor and / the Land Rights Certificate Owner request a photocopy of the credit guarantee documents and confirm the initial Creditors that the credit facility will be settled in accordance with the credit facility maturity date in accordance with the copy of the previous credit agreement between the Debtor and the Initial Creditors. The debtor also asks the Initial Creditors to prepare credit guarantee documents that will be withdrawn in accordance with the receipt of collateral that was previously submitted by the Initial Creditors to the debtor. The practice of the banking sector especially in paying off credit facilities is recommended in accordance with the maturity of the debtor's credit facility at the initial creditor in accordance with what has been agreed with the aim of avoiding the penalty of repayment of the debtor's remaining debt to the original creditor. The debtor requests a photocopy of the Land Rights Certificate and the Mortgage Certificate on the original creditor that is still attached the Mortgage Right.

Based on information from Notary CCB Indonesia Pekanbaru Branch Partners namely Mrs. Suhaimah Simanjuntak, SH, Ms. Laurensia Emilia, SH, Mr. Victor Jonathan, SH that in receiving orders from CCB Indonesia Pekanbaru Branch for signing the take over agreement, and SKMHT (Letter Power of Attorney Imposing Mortgage Rights only with credit documents in the form of a photocopy of the Certificate of Land Rights that are still attached to the Mortgage. Partner notaries make an oral check with the National Land Agency (BPN) for certificates of registered land rights ${ }^{20}$.

Furthermore, Legal Credit received information from the Marketing Bank for the schedule of binding notary credit agreements and requested from the Notary Partner to prepare a Deed of Notarial Deed. Marketing Bank will coordinate with Marketing to the initial creditor to prepare debtor credit guarantee documents in the form of Roya Letter, Debtor Debt Certificate and receipt of collateral on the same date as the fund transfer date to repay the entire debtor debt to the original creditor.

The mechanism for signing a take-over Credit Agreement with guarantee of Mortgage Rights is carried out with a schedule for signing the take-over agreement between the Debtor / First Party and the CCB Creditors of Pekanbaru / Second Party, then after signing the notary deeds before the Notary Public / PPAT Partner then submit all files to Legal Credit in the form of documents as follows:

\section{Government / Notary Certificate / PPAT Partner}

the contents of which are regarding the number and date of the binding deed

and completion period.

\section{Details of Notary fees / Partner PPAT (details of fees}

The notary must be received by the Legal Credit before the Credit Agreement or the Credit Agreement, while the original invoice / bill / receipt is submitted to the Legal Credit together with the delivery of a copy of the deed and everything related to the signing of the Debtor credit agreement that has been processed by the Notary Partner and payment on these bills to the Partner Notary after the Partner Notary has completed the settlement process.

3. Other documents that are legally required and / or required in the Approver of Credit

must exist before the Credit Agreement;

\footnotetext{
${ }^{19}$ Interview with Credit Operation Head on June 17, 2019.

${ }^{20}$ Interview with CCB Indonesia Notary Partner Pekanbaru Branch, 20 June 2019.
} 
CCB Indonesia Pekanbaru Branch in carrying out the full repayment of debtor debts to the initial creditor by transferring funds based on Covernote / Notary Certificate / PPAT Partner who poured out the signing of the deed of binding the take over agreement between the Debtor / First Party and CCB Indonesia Creditors Pekanbaru Branch /The second party. Signed of a take over agreement means that rights and obligations have been agreed upon for both parties. The specificity of the take over agreement with the guarantee of Mortgage in Article 3 expressly specifies that currently the collateral object is still in the original creditor and also in Article 4 explicitly specifies that the Debtor will transfer funds to the initial creditor from the disbursement of the credit facility Obtained Debtor from CCB Indonesia Pekanbaru Branch.

Referring to the provisions of Article 1400 Paragraph 2 of the Civil Code it states that:

"If the borrower borrows some money to pay off his debt and stipulates that the person who lent the money will replace the debtor's rights then for this subrogation to be valid, both the money lending agreement and the repayment mark must be made with an authentic deed and in the loan agreement the money must be it was explained that the money was borrowed to pay off the debt, while the next letter of repayment must explain that the payment was made with the money for which the new loaner had lent. "

Based on interviews with the Pekanbaru Branch Credit Operations Head on Notification / Covernote Notary Partner of the CCB Indonesia Pekanbaru Branch that outlines the process of notarial deed and / or PPAT (Land Deed Making Official) with a period of 3 (three) months from the date of the credit agreement $^{21}$. In view of the Cooperation Agreement between CCB Indonesia and the Notary Public / PPAT Partner there are obligations and responsibilities of the Notary Public / PPAT Partner as follows:

1. Notary / PPAT Partner is obliged to prioritize checking with the local National Land Agency (BPN) both regarding the location of the land, cleanliness of the certificate in the sense that there is no block or seizure by other parties. If there is no problem with the checking results, it can proceed with the binding process, but if there is a problem with the checking results, the Notary / PPAT Partner must submit a written notification to CCB Indonesia as soon as possible and the process is postponed until further notice.

2. Notary / PPAT Partner is obliged to issue a covernote / Notary Certificate / PPAT with the format determined by CCB Indonesia and submit it to CCB Indonesia at the same time as the process of signing the credit binding and / or binding of the collateral.

3. Notary / PPAT Partner must complete the process of making, registration until the issuance of the Mortgage Certificate (SHT) within 90 (ninety) calendar days from registration at the local National Land Agency office, the Mortgage Certificate and the Land Certificate that have been encumbered with the following Mortgage Rights with APHT (Deed of Granting Mortgage Right) already received by the First Party.

4. Notary / PPAT Partner must provide information to CCB Indonesia if the period specified and specified above does not apply when there is a delay by the local National Land Agency (BPN) Office with attachments of evidence that can be accepted by CCB Indonesia.

\footnotetext{
${ }^{21}$ Interview with Credit Operation Head on June 17, 2019.
} 
The above if related to the results of the interview with the CCB Indonesia Credit Operation Head Pekanbaru Branch on June 17, 2019 that the Notary / PPAT Partner of the CCB Indonesia Pekanbaru Branch requested an extension of the Covernote / Notary Certificate / PPAT Partner to the CCB Indoensia Pekanbaru Branch for binding the loan takeover agreement (take over) because from the National Land Agency (BPN) requesting the verification of certificates that take 1 (one) month, and there are changes in the village, sub-district in the certificate of land rights, Checking certificate of land rights that take 1 (one) week, he continued with the installation of Mortgage Rights on the Land Rights Certificate and the latest window on the issuance of the Mortgage Certificate for the interests of the CCB Indonesia Pekanbaru Branch as the holder of the Mortgage Rights. The process described above happened at the National Land Agency (BPN) of Pekanbaru City so that the Notary / PPAT Partner requests an extension of the covernote / Notary Certificate / PPAT Partner counted from 1 (one) month ahead of the date of the end of the Covernote / Notary Certificate / PPAT Partner first issued.

Based on information from the CCB Indonesia Notary Partner Pekanbaru Branch namely Mrs. Suhaimah Simanjuntak, S.H, Mrs. Laurensia Emilia, S.H, Mr. Victor Jonathan, S.H that one of the reasons for extending the Covernote / Notary Certificate / PPAT Partner ${ }^{22}$. Requests for extension of Government / Notary Certificate / PPAT Partner can also come from the Early Creditors / Banks (which are taken over), as follows:

1. Credit operational centralization system, for example the Custody Centralized system at the head office of the Initial Creditors in the depository. Debtor collateral is at the head office, so it requires a period of time to collect collateral - debtor guarantees at the head office and even exceed the SKMHT period Mortgage) so that the solution is that the Debtor is present again to sign the extension of the SKMHT (Power of Attorney Letter Imposing Mortgage Rights) period.

2. Another obstacle faced by the binding of a take over loan agreement is that the date of the Roya Letter and the Certificate of Settlement issued by the Initial Creditors is different from the date of repayment transfers obtained by the Debtor from the disbursement of credit facilities at CCB Indonesia Pekanbaru Branch. to be revised and communicated to the Initial Creditors / Banks (which are taken over) so that they are in conformity with the Notification of Taking Credit Debtor Facilities to the Bank that has been taken over as sent to the Initial Creditors / Banks (which are taken over) because of all collateral documents The credit will be continued to the local BPN (National Land Agency).

In connection with the SKMHT (Warrant of Authorization of Liability) Act, the Accessoir or additional guarantee of the Credit Acquisition Agreement is the principal or principal agreement. SKMHT (Warrant of Authorization of Liability) with a period of 1 (one) month from the date of the credit agreement. In accordance with the provisions of Article 15 Section 3 of the Land Rights Act, the Warrant of Authorization of the Land Titles (SKMHT) of registered land rights must be followed by the making of the Grant of Rights (APHT) no later than 1 (one) month after the grant, by Article 15 Section 3 of the Copyright Act. The conditions under which the SKMHT (Warrant of Authorization of Assignment) has been signed between the Debtor / First Party and the Creditors / Second Parties within a period of 1 (one) month from the date of the credit, may be extended by the adjudication of the debtor / First Parties and Creditors / Second Parties due to the duration of the SKMHT (Warrant of Authorization of Liability) has passed and the signing of the APHT (Assignment of Rights Act) in the interest of the CCB Indonesia Pekanbaru Branch has not been made.

\footnotetext{
${ }^{22}$ Wawancara dengan Notaris Rekanan CCB Indonesia Cabang Pekanbaru,tanggal 20 Juni 2019.
} 
Based on the above description of the MCMC (Referring to the Right to Burden of Rights) it refers to the clarification of the provisions of Article 15 Section 6 of the Copyright Law that imposes that the expiry of the SKMHT (Warrant of Authorization of Liability) is intended to prevent a delay in the execution of that power. This provision does not cover the possibility of an extension of the SKMHT. In connection with this research, the theory of legal certainty forms the basis for creditors and debtors in carrying out their obligations under the agreement they have made in connection with the Take Over Credit Agreement with PT Bank China Construction Bank Indonesia Tbk. Pekanbaru Branch.

\section{Conclusion}

The Credit Acquisition Agreement (take over) as the principal agreement is continued with the signing of the SKMHT on the credit guarantee object between the Debtor / First Party and the CCB Indonesia Credit Union / Second Party with the original conditions of the Land Rights Certificate and the Certificate of Liability (SHT) the right of preference is vested in the original Creditors as the Holder of the Liability and will be enforced by Roya the Liability on the same date as the date of the signing of the credit. In connection with this research, the theory of legal certainty forms the basis for creditors and debtors in carrying out their obligations under the agreement they have made in connection with the Take Over Credit Agreement with PT Bank China Construction Bank Indonesia Tbk. Pekanbaru Branch.

\section{References}

\section{Books}

Djaja S. Meliala, 2008, Penuntun Praktis Perjanjian Pemberian Kuasa Menurut Kitab Undang-Undang Hukum Perdata, Nuansa Alulia, Bandung.

Djoni S. Gazali, Rachmadi Usman, 2010, Hukum Perbankan, Sinar Grafika, Jakarta.

Hartono Hadisaputro,1984,Seri Hukum Perdata Pokok-Pokok Hukum Perdata dan Hukum Jaminan,Liberty,Yogyakarta.

Hasanudin Rahman Daeng Naja, 2005, Hukum Kredit dan Bank Garansi - The Bankers Hand Book, PT.Citra Aditya Bakti, Bandung.

Herlien Budiono,2008,Kumpulan Tulisan Hukum Perdata di Bidang Kenotariatan, Citra Aditya Bakti,Bandung.

Hermansyah, 2008, Hukum Perbankan Nasional Indonesia, Prenada Media Group, Jakarta.

John M. Echols dkk, 1990, Kamus Inggris-Indonesia, PT. Gramedia Pustaka Utama,Jakarta.

Mariam Darus Badrulzaman,2000,Beberapa Permasalahan Hukum Hak Jaminan, Jurnal Hukum Bisnis Vol.11,Jakarta. 
Neni Sri Imaniyati,2009, Hukum Bisnis Telaah tentang Pelaku dan Kegiatan Ekonomi, Graha Ilmu, Yogjakarta.

Rachmadi Usman,2009, Hukum Jaminan Keperdataan,Sinar Grafika, Jakarta.

R. Subekti, 1987, Hukum Perjanjian, PT. Intermasa, Jakarta.

Sjaifurrachman, 2011,Aspek Pertanggungjawaban Notaris dalam Pembuatan Akta,Mandar Maju, Bandung.

\section{Legislations}

Undang - Undang Dasar Negara Republik Indonesia Tahun 1945.

Undang-Undang Republik Indonesia Nomor 5 Tahun 1960 tentang Peraturan Pokok-Pokok Agraria.

Undang-Undang Republik Indonesia Nomor 4 Tahun 1996 tentang Hak Tanggungan atas Tanah Beserta Benda-Benda yang Berkaitan dengan Tanah.

Undang-Undang Republik Indonesia Nomor 10 Tahun 1998 tentang Perubahan Atas Undang-Undang Nomor 7 Tahun 1992.

Undang-Undang Republik Indonesia Nomor 2 Tahun 2014 tentang Perubahan Atas Undang-Undang Nomor 30 Tahun 2004 tentang Jabatan Notaris.

\section{Others}

https://www.pinjamandanatunai.info, dikunjungi pada tanggal 30 Desember 2018.

SOP ( Standard Operation Procedure) PT Bank China Construction Bank Indonesia Tahun 2013.

\section{Copyrights}

Copyright for this article is retained by the author(s), with first publication rights granted to the journal.

This is an open-access article distributed under the terms and conditions of the Creative Commons Attribution license (http://creativecommons.org/licenses/by/4.0/). 